\title{
The Impact of Teaching Reform Conflict and Job Burnout on Curriculum Implementation in Senior High School English Teachers
}

\author{
Li Luo \\ China West Normal University, Sichuan, Nanchong, China
}

\begin{abstract}
Recently, with the reform of the college entrance examination English system, the requirements for teachers' professional development and teaching abilities are increasing. Thus, the burden and pressure of teachers are becoming more and more serious. Meanwhile, Teachers' teaching reform conflict and job burnout are becoming more serious than before. Questionnaires and interviews will be used in this paper to investigate the teaching reform of senior high school English teachers. The present situation of conflict and job burnout and its influence on curriculum implementation are analyzed. Effective information will be provided for education departments and educational institutions, so that they can take appropriate measures for this reform and job burnout to ensure the quality of the implementation of the curriculum.
\end{abstract}

Index Terms - conflict of teaching reform, job burnout, curriculum implementation

\section{INTRODUCTION}

English teachers in high school today bear so more pressures, teaching tasks and professional challenges than other English teachers that many teachers are unbearable. In addition, in recent years, the English teachers have to participate in many kinds of training such as the reform of the English system and the further education. Therefore, the phenomenon of teaching reform conflict and job burnout is gradually increasing because of the heavy pressure. Under such circumstances, how will the implementation of the curriculum be affected? Teachers Resistance in Education Reform refers to the phenomenon that some teachers can not really walk into the educational reform and even resist the implementation of the reform because of the understanding and recognition of the educational reform, their own ability and the degree of benefit (Pamela Freilich Hjelle, 2001) .Job Burnout is based on three dimensions of the individual stress, interpersonal relationship and self evaluation of burnout. It is proposed that job burnout is a syndrome of emotional exhaustion, disintegration of personality and the decrease of personal accomplishment in the individual engaged in the helping industry. Educational conflict and job burnout are a threat to the professional development, teaching quality and teaching achievements of English teachers.

At present, although the researchers have made some achievements in the study of teachers' job burnout, there are few studies on the phenomenon of teaching reform in high school English teachers, so this paper will investigate and study it. This will help to provide effective information for educational departments, educational institutions and schools, and improve teachers' teaching quality, teaching results and professional development.

\section{LITERATURE REVIEW}

Foreign research review:

Maslach,C \& S.Jackson summed up the MBI job burnout teacher scale in its "The Measurement of Experienced" (Maslach, C \& S. Jackson, 1981). The main body of the scale is 22 statements describing the work experience, attitude and feeling of the individual, and mainly measure the occupational fatigue of three aspects of individual emotional exhaustion, dehumanization and personal accomplishment. It provides valuable experience and reference for other researchers. They summed up the teachers' impact on teaching reform by psychological, personal, school-based cultural and organizational factors in Teachers resistance to educational change in the United Arab Emirates (Ibrahim, A.S., Al-Kaabi, A., \& El- Zaatari,W.J, 2013).

Domestic research review:

Cheng Xiaotang (Chen, 2006) found that the overall burnout of male teachers is slightly lower than that of female teachers in foreign language subjects. The job burnout of excellent teachers or backbone teachers is better than that of other teachers'. Fan Lin, Li Mengli, Shi Hongwei, \& Liang Junjun (Fan, 2017) also found that the sense of efficacy has a significant negative correlation with job burnout. Self concept is an important variable to explain job burnout .Wang Fang\& Xu Yan (Wang, 2004) found that the teacher's teaching age in 11-20 years of teachers' exhaustion degree is higher. Niu Lihua and Zou Meng (Niu, 2010) found that conflict of interests, emotional drive and institutional coercion will become the resistance. The study of Qiu Bi group (Qiu, 2008) found that older teachers and married teachers experienced more emotional exhaustion, dehumanization, and cognitive exhaustion than young teachers and unmarried 
teachers. Teachers in senior high school were more likely to face the threat of cognitive depletion than those of junior high school teachers. The study of Xiao Hui (Xiao, 2011) found that teachers' job burnout damaged teachers' physical and mental health, reduced teachers' consciousness and enthusiasm, delayed teachers' career development and destroyed the stability of teachers' team and constitutes.

In general, researchers at home and abroad have made a thorough study of job burnout, but the research object is not specific and pertinent, especially in high school English teachers' teaching reform. In view of this, this study uses the related scale to examine the impact of teaching reform conflict and job burnout on the implementation of the curriculum in city, countryside and Xinjiang of high school English teachers. The following questions are specifically examined: (1) is there a correlation between teacher education conflict and job burnout? If there is, what is the relationship. (2) what is the current situation of English teachers' conflict of teaching and job burnout in cities, rural areas and Xinjiang? (3) whether teachers' teaching reform conflict and job burnout can influence curriculum implementation.

\section{RESEARCH AND DESIGN}

i. Subjects: The subjects of this study are high school English teachers in three districts of the city, countryside and Xinjiang. A total of 385 questionnaires were issued, 350 were recovered, and 310 valid questionnaires were obtained. Among the subjects, 100 and 210 male and female teachers were awarded (20-29. 30-39, 40-49, over 50 years old) teaching age (1-10 years, 11-20 years, more than 21 years) of the teachers' Award (no award, outstanding teachers, backbone teachers, excellent + backbone teachers).

ii. Research tools: the data are recorded and counted with SPSS10.0, and the MBI scale is used to analyze the job burnout of teachers. At the same time, the questionnaire on the teaching reform of high school English teachers is compiled, and the 5 grade scoring method is adopted from psychological factors, individual factors, school-based culture and organization of four organizations. The investigation was carried out by factors.

\section{Discussions AND Results}

TABLE 1:

JOB BURNOUT OF TEACHERS OF DIFFERENT SEXES

\begin{tabular}{|l|l|l|l|l|l|}
\hline & Sex & Number & Average & Standard deviation & T examination (saliency) \\
\hline \multirow{2}{*}{ Emotional exhaustion } & Male & 100 & 17.62 & 11.49 & \multirow{2}{*}{0.72} \\
\cline { 2 - 5 } & Female & 210 & 18.14 & 10.78 & \multirow{2}{*}{0.36} \\
\hline \multirow{2}{*}{ Dehumanization } & Male & 100 & 6.08 & 4.73 & \multirow{2}{*}{0.22} \\
\cline { 2 - 6 } & Female & 210 & 6.69 & 4.94 & 6.86 \\
\hline \multirow{2}{*}{$\begin{array}{l}\text { Personal } \\
\text { accomplishment }\end{array}$} & Male & 100 & 37.41 & 7.16 & \\
\cline { 2 - 6 } & Female & 210 & 36.28 & \\
\hline
\end{tabular}

From table 1, we can see that the score of female teachers is higher than that of male teachers in the two dimensions of emotional exhaustion and dehumanization. In the sense of personal accomplishment, the score of male teachers is higher than that of female teachers. That is to say, although the differences between the three dimensions do not reach a significant level, the overall burnout of male teachers is slightly lower than that of female teachers. Among the foreign language teachers, the majority of the teachers are female teachers. Male teachers who remain in the field of foreign language teaching are often those who are interested in foreign language teaching or have achieved success in foreign language teaching. Therefore, in foreign language discipline, male teachers are slightly less general burnout than female teachers. According to the survey data, the number of city teachers is the highest in the whole table, followed by Xinjiang and the rural area.

TABLE 2:

OCCUPATIONAL BURNOUT OF TEACHERS OF DIFFERENT AGES

\begin{tabular}{|c|c|c|c|c|c|}
\hline & Ages & Numbers & Average & Standard deviation & $\mathrm{T}$ examination (saliency) \\
\hline \multirow{4}{*}{ Emotional exhaustion } & $20-29$ & 75 & 17.76 & 11.34 & \multirow{4}{*}{0.528} \\
\hline & $30-39$ & 155 & 17.59 & 10.85 & \\
\hline & $40-49$ & 66 & 19.9 & 10.75 & \\
\hline & Above 50 & 14 & 15.62 & 11.04 & \\
\hline \multirow{4}{*}{ Dehumanization } & $20-29$ & 75 & 6.92 & 5.13 & \multirow{4}{*}{0.103} \\
\hline & $30-39$ & 155 & 6.25 & 4.95 & \\
\hline & $40-49$ & 66 & 7.2 & 4.21 & \\
\hline & Above 50 & 14 & 3 & 3.92 & \\
\hline \multirow{4}{*}{ Personal accomplishment } & $20-29$ & 75 & 36.48 & 6.58 & \multirow{4}{*}{0.353} \\
\hline & $30-39$ & 155 & 36.54 & 7.4 & \\
\hline & $40-49$ & 66 & 36.2 & 6.72 & \\
\hline & Above 50 & 14 & 41 & 7.52 & \\
\hline
\end{tabular}


TABLE 3:

OCCUPATIONAL BURNOUT OF TEACHERS OF DIFFERENT TEACHING AGES

\begin{tabular}{|c|c|c|c|c|c|}
\hline & Teaching ages & Numbers & Average & Standard deviation & $\mathrm{T}$ examination (saliency) \\
\hline \multirow{3}{*}{ Emotional exhaustion } & $1-10$ & 137 & 18.75 & 11.02 & \multirow{3}{*}{0.414} \\
\hline & $11-20$ & 123 & 17 & 10.76 & \\
\hline & Above 21 & 50 & 18.7 & 11.38 & \\
\hline \multirow{3}{*}{ Dehumanization } & $1-10$ & 137 & 7.02 & 5.16 & \multirow{3}{*}{0.276} \\
\hline & $11-20$ & 123 & 6.05 & 4.61 & \\
\hline & Above 21 & 50 & 6.25 & 4.72 & \\
\hline \multirow{3}{*}{ Personal accomplishment } & $1-10$ & 137 & 34.92 & 7.43 & \multirow{3}{*}{$0.002 *$} \\
\hline & $11-20$ & 123 & 38 & 6.51 & \\
\hline & Above 21 & 50 & 37.53 & 6.69 & \\
\hline
\end{tabular}

It can be seen from table 2 and 3 that job burnout is related to the length of teachers' employment. Therefore, studies on occupational burnout usually analyze the factors of age and educational age. The survey divided the subjects into four age groups, namely 20-29 years old, 30-39 years old, 40-49 years old and over 50 years old. The subjects were divided into three age groups, namely 1-10 years, 11-20 years and over 20 years. From table 2 and table 3, the different age and teaching experience of the teachers there were no significant differences in terms of job burnout, only in terms of personal accomplishment, teaching experience in 11-20 years and more than 20 years of teachers scored significantly higher than that of 1-10 years of teaching experience for teachers, variance test of significance of 0.002 . It is worth noting that in terms of age, and over the age of 50 teachers (14) in the three dimensions of score with other age groups of teachers have obvious difference and show the teacher's job burnout situation is much better than other age groups of teachers. An examination of the backgrounds of the 14 teachers revealed that, with the exception of one, all but 13 were excellent teachers and/or key teachers (see discussion below). According to the questionnaire data, the number of urban teachers occupies the highest proportion in the whole table, followed by Xinjiang, followed by rural areas.

TABLE 4:

TEACHERS' AWARDS AND JOB BURNOUT

\begin{tabular}{|l|l|l|l|l|}
\hline & Teachers' awards & Numbers & Average & $\begin{array}{l}\text { Standard } \\
\text { deviation }\end{array}$ \\
\hline \multirow{5}{*}{ Emotional exhaustion } & $\begin{array}{l}\text { T examination } \\
\text { (saliency) }\end{array}$ \\
\cline { 2 - 5 } & No awards & 103 & 18.78 & 11.04 \\
\cline { 2 - 5 } & Good teachers & 86 & 20.05 & 10.66 \\
\cline { 2 - 5 } & Backbone teachers & 54 & 16.76 & 10.49 \\
\cline { 2 - 5 } & Good teacher and backbone teachers & 67 & 15.21 & 11.14 \\
\hline \multirow{5}{*}{$\begin{array}{l}\text { Pehumanization } \\
\text { accomplishment }\end{array}$} & No awards & 103 & 7.67 & 4.97 \\
\cline { 2 - 5 } & Good teachers & 86 & 7.12 & 5.07 \\
\cline { 2 - 5 } & Backbone teachers & 54 & 5.46 & 4 \\
\cline { 2 - 5 } & Good teacher and backbone teachers & 67 & 4.78 & 4.59 \\
\cline { 2 - 4 } & No awards & 103 & 34.12 & 7.62 \\
\cline { 2 - 4 } & Good teachers & 86 & 36.18 & 6.95 \\
\cline { 2 - 4 } & Gackbone teachers & 54 & 37.75 & 6.43 \\
\cline { 2 - 4 } & Good teacher and backbone teachers & 67 & 39.95 & 5.27 \\
\hline
\end{tabular}

$$
* \mathrm{p}<0.05 ; * * \mathrm{p}<0.01 ; * * * \mathrm{p}<0.001
$$

The data from table 4, who obtain the title of outstanding teachers or backbone teachers of teachers' job burnout situation is much better than who do not have any title of teacher especially the good teacher and backbone teachers. They scored lowest in emotional exhaustion and dehumanization, but scored the highest in terms of personal accomplishment. The results of variance test show that the differences between groups of three dimensions have reached a significant level. It is worth noting that the best teachers score highest in terms of emotional exhaustion (which is the most severe). According to the questionnaire data, the number of urban teachers occupies the highest proportion in the whole table, followed by Xinjiang, followed by rural areas.

TABLE 5:

PSYCHOLOGICAL FACTORS INFLUENCING TEACHERS' RESISTANCE TO TEACHING REFORM

\begin{tabular}{|l|l|l|l|l|}
\hline & Psychological factors & Average & Standard deviation & Agreed percentage \\
\hline 1 & With a strong passion to participate in the reform & 4.06 & 0.878 & $80.8 \%$ \\
\hline 2 & Doubt your expertise & 3.56 & 1.274 & $59.3 \%$ \\
\hline 3 & Fear of losing your job & 3.09 & 1.403 & $43.2 \%$ \\
\hline 4 & Fear of increasing workload and tasks & 3.23 & 1.344 & $49.4 \%$ \\
\hline 5 & Doubt your ability to accept new knowledge & 2.20 & 1.195 & $17.7 \%$ \\
\hline
\end{tabular}

From table 5, it can be seen that the enthusiasm of willing to participate in teaching reform has become the most influential factor, and the concern of their own professional level is a factor worth considering. and it has little influence on their ability to accept new knowledge. 
TABLE 6:

PERSONAL FACTORS INFLUENCING TEACHERS' RESISTANCE TO TEACHING REFORM

\begin{tabular}{|l|l|l|l|l|}
\hline & Personal factors & Average & $\begin{array}{l}\text { Standard } \\
\text { deviation }\end{array}$ & $\begin{array}{l}\text { Agreed } \\
\text { percentage }\end{array}$ \\
\hline 1 & Demand for educational reform & 3.70 & 1.086 & $69.8 \%$ \\
\hline 2 & Believe that you can complete the teaching reform & 4.01 & 0.956 & $79.3 \%$ \\
\hline 3 & Be clear about your role in teaching reform & 3.54 & 1.100 & $59.3 \%$ \\
\hline 4 & Afraid that the reform will affect the original teaching & 2.83 & 1.213 & $32.4 \%$ \\
\hline 5 & $\begin{array}{l}\text { We will oppose educational reform that does not conform to } \\
\text { norms and values }\end{array}$ & 2.62 & 1.170 & $22.7 \%$ \\
\hline
\end{tabular}

From table 6, we can see that the proportion of the importance of individual ability in teaching reform is $79.3 \%$ (average value 4.01). According to the questionnaire, the proportion of urban teachers is the highest, followed by the teachers in Xinjiang, and the last of the rural teachers.

TABLE 7:

SCHOOL-BASED CULTURAL FACTORS INFLUENCING TEACHERS' RESISTANCE TO TEACHING REFORM

\begin{tabular}{|c|c|c|c|c|}
\hline & School-based cultural factors & Average & $\begin{array}{l}\text { Standard } \\
\text { deviation }\end{array}$ & $\begin{array}{l}\text { Agreed } \\
\text { percentage }\end{array}$ \\
\hline 1 & $\begin{array}{l}\text { Educational reform conforms to the school standards and } \\
\text { values }\end{array}$ & 3.85 & 0.875 & $70.6 \%$ \\
\hline 2 & $\begin{array}{l}\text { Educational reform is a regular training and learning in } \\
\text { schools }\end{array}$ & 4.01 & 0.956 & $79.3 \%$ \\
\hline 3 & $\begin{array}{l}\text { The school provides enough time to complete the teaching } \\
\text { reform }\end{array}$ & 3.47 & 1.242 & $54.6 \%$ \\
\hline 4 & $\begin{array}{l}\text { Schools work with teachers to plan new education } \\
\text { perspectives }\end{array}$ & 4.02 & 0.938 & $79.2 \%$ \\
\hline 5 & $\begin{array}{l}\text { The school encourages teachers to cooperate in exploring } \\
\text { teaching reform }\end{array}$ & 4.22 & 0.840 & $85.1 \%$ \\
\hline 6 & $\begin{array}{l}\text { Schools provide support in the implementation of educational } \\
\text { reform }\end{array}$ & 4.05 & 0.889 & $76.4 \%$ \\
\hline
\end{tabular}

As can be seen from table 7, the school's agreement on teacher cooperation for teaching reform is $85.1 \%$. It can be seen that the completion of educational reform in schools requires not only the support of schools, but also the unity and cooperation between teachers. Teachers offer more training opportunities in urban secondary schools, and there are more cooperation among teachers, followed by teachers in Xinjiang, and rural teachers in the end.

TABLE 8:

ORGANIZATIONAL FACTORS INFLUENCING TEACHERS' CONFLICT IN TEACHING REFORM

\begin{tabular}{|l|l|l|l|l|}
\hline & Organizational factors & Average & $\begin{array}{l}\text { Standard } \\
\text { deviation }\end{array}$ & $\begin{array}{l}\text { Agreed } \\
\text { percentage }\end{array}$ \\
\hline 1 & $\begin{array}{l}\text { Teachers' willingness to participate in the reform has been } \\
\text { assessed }\end{array}$ & 3.56 & 1.126 & $62.7 \%$ \\
\hline 2 & The purpose of the reform is clear & 3.34 & 1.263 & $52.9 \%$ \\
\hline 3 & The process of teaching reform is logical and understandable & 3.46 & 1.152 & $44.5 \%$ \\
\hline 4 & The implementation time of the reform is effective & 3.24 & 1.240 & $47.8 \%$ \\
\hline 5 & Educational reform activities meet the needs & 2.62 & 1.170 & $22.7 \%$ \\
\hline 6 & Provide effective resources to complete teaching reform & 4.27 & 0.875 & $85.1 \%$ \\
\hline 7 & The teacher was directed to complete the teaching reform & 3.57 & 1.111 & $58.8 \%$ \\
\hline 8 & New skills are available & 4.23 & 0.970 & $83.9 \%$ \\
\hline 9 & The completion of the reform will be rewarded & 3.44 & 1.305 & $52.2 \%$ \\
\hline 10 & Reform assessment is effective & 3.50 & 1.135 & $59.2 \%$ \\
\hline 11 & The school organizes educational reform too many times & 3.67 & 1.012 & $63.9 \%$ \\
\hline
\end{tabular}

As can be seen from table 8, whether the resources to complete the teaching reform are effective and whether teachers can acquire new skills in teaching reform account for $85.1 \%$ and $83.9 \%$ respectively. In cities, teachers acquire more resources and learn skills, followed by teachers in Xinjiang, and rural teachers in the end.

\section{CONCLUSIONS}

In this study, the burnout of senior high school English teachers and the influencing factors of educational reform were investigated and analyzed by using a teacher's job burnout inventory (MBI - Educators survey) and "high school English teacher educational reform resistance questionnaire" in urban, rural, and Xinjiang. In this study, the following conclusions are drawn:(1) Through regression analysis, it is found that the more obvious the teachers' resistance to educational reform, the higher their degree of job burnout is. (2) Job burnout of English teachers in urban high schools is more serious than that of English teachers in Xinjiang and rural high schools. (3) In the foreign language discipline, the overall burnout degree of male teachers is slightly lower than that of female teachers. (4) Teachers of different age and teaching age there were no significant differences in terms of job burnout, but in terms of personal accomplishment, teaching experience in 11-20 years and more than 20 years of teachers scored significantly higher than that of 1-10 
years teaching experience for teachers. (5) Good teachers or backbone teachers' job burnout situation is much better than other teachers especially a good teacher and backbone teachers. Although they scored lowest in emotional exhaustion and dehumanization, score the highest in terms of personal accomplishment. (6) Whether it is the phenomenon of resistance to teaching reform or job burnout, it will affect teachers' teaching, affect the implementation of the whole curriculum and reduce the effectiveness of curriculum implementation.

\section{LIMITATIONS AND IMPLICATIONS}

Effective information will be provided for education departments and educational institutions, so that they can take appropriate measures for this reform and job burnout to ensure the quality of the implementation of the curriculum. However, the sampling area of this study is large and the variables of the sample are not conducive to control. There are many schools involved in the recovery questionnaire. Future research should also narrow down the scope and improve the reliability and validity of the sample.

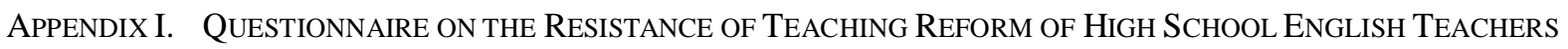

Dear teachers,

Hello! Thank you for helping us complete this questionnaire in your busy schedule! This is a questionnaire to understand your views on the educational reform, so please fill in according to your own actual situation. This questionnaire is anonymous. The results are only for scientific research purposes. Please do not hesitate. I will keep your answers confidential. I hope you can read it carefully and help us complete a high-quality questionnaire. Thank you for your cooperation!

Remark: The scale uses the 5 level scoring method, and the subjects use 1-5 5 figures to show the degree of recognition for each statement. 1 is "strongly agree", 2 says "agree", 3 means "disagree", 4 means "generally disagree," 5 says "strongly disagree".

Please tick the appropriate number according to your own feeling and experience. 


\begin{tabular}{|c|c|c|c|c|c|c|}
\hline Item & Influencing factors & $\begin{array}{l}\text { Strongly } \\
\text { agree }\end{array}$ & Agree & Disagree & $\begin{array}{l}\text { Generally } \\
\text { disagree }\end{array}$ & $\begin{array}{l}\text { Strongly } \\
\text { disagree }\end{array}$ \\
\hline & Psychological factors & \multicolumn{5}{|c|}{$\begin{array}{l}\text { The score in this dimension is equal to the sum of the scores of all items } \\
\text { divided by } 5\end{array}$} \\
\hline 1 & With a strong passion to participate in the reform & 1 & 2 & 3 & 4 & 5 \\
\hline 2 & Doubt your expertise & 1 & 2 & $\mathbf{3}$ & 4 & 5 \\
\hline 3 & Fear of losing your job & 1 & 2 & 3 & 4 & 5 \\
\hline 4 & Fear of increasing workload and tasks & 1 & 2 & 3 & 4 & 5 \\
\hline \multirow[t]{2}{*}{5} & Doubt your ability to accept new knowledge & 1 & 2 & 3 & 4 & 5 \\
\hline & Personal factors & \multicolumn{5}{|c|}{$\begin{array}{l}\text { The score in this dimension is equal to the sum of the scores of all items } \\
\text { divided by } 5\end{array}$} \\
\hline 1 & Demand for educational reform & 1 & 2 & 3 & 4 & 5 \\
\hline 2 & Believe that you can complete the teaching reform & 1 & 2 & 3 & 4 & 5 \\
\hline 3 & Be clear about your role in teaching reform & 1 & 2 & 3 & 4 & 5 \\
\hline 4 & Afraid that the reform will affect the original teaching & 1 & 2 & 3 & 4 & 5 \\
\hline \multirow[t]{2}{*}{5} & $\begin{array}{l}\text { We will oppose educational reform that does not conform } \\
\text { to norms and values }\end{array}$ & 1 & 2 & 3 & 4 & 5 \\
\hline & School-based cultural factors & \multicolumn{5}{|c|}{$\begin{array}{l}\text { The score in this dimension is equal to the sum of the scores of all items } \\
\text { divided by } 6\end{array}$} \\
\hline 1 & $\begin{array}{l}\text { Educational reform conforms to the school standards and } \\
\text { values }\end{array}$ & 1 & 2 & 3 & 4 & 5 \\
\hline 2 & $\begin{array}{l}\text { Educational reform is a regular training and learning in } \\
\text { schools }\end{array}$ & 1 & 2 & 3 & 4 & 5 \\
\hline 3 & $\begin{array}{l}\text { The school provides enough time to complete the teaching } \\
\text { reform }\end{array}$ & 1 & 2 & 3 & 4 & 5 \\
\hline 4 & $\begin{array}{l}\text { Schools work with teachers to plan new education } \\
\text { perspectives }\end{array}$ & 1 & 2 & 3 & 4 & 5 \\
\hline 5 & $\begin{array}{l}\text { The school encourages teachers to cooperate in exploring } \\
\text { teaching reform }\end{array}$ & 1 & 2 & 3 & 4 & 5 \\
\hline \multirow[t]{2}{*}{6} & $\begin{array}{l}\text { Schools provide support in the implementation of } \\
\text { educational reform }\end{array}$ & 1 & 2 & 3 & 4 & 5 \\
\hline & Organizational factors & \multicolumn{5}{|c|}{$\begin{array}{l}\text { The score in this dimension is equal to the sum of the scores of all items } \\
\text { divided by } 11\end{array}$} \\
\hline 1 & $\begin{array}{l}\text { Teachers' willingness to participate in the reform has been } \\
\text { assessed }\end{array}$ & 1 & 2 & 3 & 4 & 5 \\
\hline 2 & The purpose of the reform is clear & 1 & 2 & $\mathbf{3}$ & 4 & 5 \\
\hline 3 & $\begin{array}{l}\text { The process of teaching reform is logical and } \\
\text { understandable }\end{array}$ & 1 & 2 & 3 & 4 & 5 \\
\hline 4 & The implementation time of the reform is effective & 1 & 2 & 3 & 4 & 5 \\
\hline 5 & Educational reform activities meet the needs & 1 & 2 & 3 & 4 & 5 \\
\hline 6 & Provide effective resources to complete teaching reform & 1 & 2 & 3 & 4 & 5 \\
\hline 7 & The teacher was directed to complete the teaching reform & 1 & 2 & 3 & 4 & 5 \\
\hline 8 & New skills are available & 1 & 2 & 3 & 4 & 5 \\
\hline 9 & The completion of the reform will be rewarded & 1 & 2 & 3 & 4 & 5 \\
\hline 10 & Reform assessment is effective & 1 & 2 & 3 & 4 & 5 \\
\hline 11 & The school organizes educational reform too many times & 1 & 2 & 3 & 4 & 5 \\
\hline
\end{tabular}

\section{APPENDIX II. TEACHER Job BURnOUT QuestionnAIRE}

Dear teachers,

Hello! Thank you for helping us complete this questionnaire in your busy schedule! This is a questionnaire of understanding your work situation, so please fill in according to your own actual situation. This questionnaire is anonymous. The results are only for scientific research purposes. Please do not hesitate. I will keep your answers confidential. I hope you can read it carefully and help us complete a high-quality questionnaire. Thank you for your cooperation!

Part I:

I Gender:

II Age (please fill in one year) :

III The length of service:

IV Teaching age:

V Final education:

VI Title:

VII Teaching grade this term:

VIII Is the class teacher this term?

IX Marital status:

X Awards or honors: 


\begin{tabular}{|l|l|}
\hline Received awards or honors & (Please tick this column) \\
\hline No awards & \\
\hline Good teachers & \\
\hline Backbone teachers & \\
\hline Good teacher and backbone teachers & \\
\hline
\end{tabular}

Part II

According to your own feelings and experience, you can judge the frequency of their occurrence in your unit or in your body, and underline on the appropriate number.

Remark: The scale uses a 7-level scoring method, and subjects use 7 numbers, 1-7, to represent the frequency of situations described in each statement. 1 says "never", 2 says "several times in a year or less", 3 means " once a month or less", 4 means " a few times a month," 5means" once a week," 6 means "several times a week," 7 says "every day".

\begin{tabular}{|c|c|c|c|c|c|c|c|c|}
\hline Number & Items & never & $\begin{array}{l}\text { several times } \\
\text { in a year or } \\
\text { less }\end{array}$ & $\begin{array}{l}\text { once a } \\
\text { month or } \\
\text { less }\end{array}$ & $\begin{array}{l}\text { a few } \\
\text { times a } \\
\text { month }\end{array}$ & $\begin{array}{l}\text { once a } \\
\text { week }\end{array}$ & $\begin{array}{l}\text { several } \\
\text { times a } \\
\text { week }\end{array}$ & $\begin{array}{l}\text { every } \\
\text { day }\end{array}$ \\
\hline & Emotional exhaustion & \multicolumn{7}{|c|}{ The score in this dimension is equal to the sum of the scores of all items divided by 6} \\
\hline 1 & $\begin{array}{l}\text { I often feel overwhelmed and exhausted by } \\
\text { my teaching work }\end{array}$ & 1 & 2 & 3 & 4 & 5 & 6 & 7 \\
\hline 2 & I often ignore some stubborn students & 1 & 2 & 3 & 4 & 5 & 6 & 7 \\
\hline 3 & $\begin{array}{l}\text { I think teaching has made me less } \\
\text { enthusiastic than before }\end{array}$ & 1 & 2 & 3 & 4 & 5 & 6 & 7 \\
\hline 4 & I feel tired of working every day & 1 & 2 & 3 & 4 & 5 & 6 & 7 \\
\hline 5 & I'm frustrated with my teaching job & 1 & 2 & 3 & 4 & 5 & 6 & 7 \\
\hline \multirow[t]{2}{*}{6} & $\begin{array}{l}\text { Dealing with students and colleagues all day } \\
\text { makes me feel under great pressure }\end{array}$ & 1 & 2 & 3 & 4 & 5 & 6 & 7 \\
\hline & Dehumanization & \multicolumn{7}{|c|}{ The score in this dimension is equal to the sum of the scores of all items divided by 6} \\
\hline 1 & $\begin{array}{l}\text { I don't care what happened to my students } \\
\text { and colleagues recently }\end{array}$ & 1 & 2 & 3 & 4 & 5 & 6 & 7 \\
\hline 2 & $\begin{array}{l}\text { I worry that the job at education has given } \\
\text { me a growing sense of indifference }\end{array}$ & 1 & 2 & 3 & 4 & 5 & 6 & 7 \\
\hline 3 & $\begin{array}{l}\text { I feel that teaching makes me cold and } \\
\text { heartless, sometimes treating students like } \\
\text { inanimate objects }\end{array}$ & 1 & 2 & 3 & 4 & 5 & 6 & 7 \\
\hline 4 & $\begin{array}{l}\text { I often feel helpless in the face of students' } \\
\text { problems }\end{array}$ & 1 & 2 & 3 & 4 & 5 & 6 & 7 \\
\hline 5 & $\begin{array}{l}\text { I feel a lot of pressure to be with the students } \\
\text { all day }\end{array}$ & 1 & 2 & 3 & 4 & 5 & 6 & 7 \\
\hline \multirow[t]{2}{*}{6} & $\begin{array}{l}\text { Sometimes I feel I have no energy to face } \\
\text { teaching and student work }\end{array}$ & 1 & 2 & 3 & 4 & 5 & 6 & 7 \\
\hline & Personal accomplishment & \multicolumn{7}{|c|}{ The score in this dimension is equal to the sum of the scores of all items divided by 5} \\
\hline 1 & $\begin{array}{l}\text { I can deal with work or student problems } \\
\text { effectively }\end{array}$ & 1 & 2 & 3 & 4 & 5 & 6 & 7 \\
\hline 2 & $\begin{array}{l}\text { I can easily understand how students feel } \\
\text { about things }\end{array}$ & 1 & 2 & 3 & 4 & 5 & 6 & 7 \\
\hline 3 & $\begin{array}{l}\text { I think the teaching work of education is very } \\
\text { valuable }\end{array}$ & 1 & 2 & 3 & 4 & 5 & 6 & 7 \\
\hline 4 & $\begin{array}{l}\text { I often feel very touched by the management } \\
\text { of students' class }\end{array}$ & 1 & 2 & 3 & 4 & 5 & 6 & 7 \\
\hline 5 & $\begin{array}{l}\text { At work, I can deal with some emotional } \\
\text { conflicts calmly }\end{array}$ & 1 & 2 & 3 & 4 & 5 & 6 & 7 \\
\hline
\end{tabular}

\section{REFERENCES}

[1] Cheng Xiao Tang. (2006). Job burnout survey of English teachers: Educational Research on Foreign Languages \&Arts, 4, 8-11.

[2] Fan Lin, Li Mengli, Shi Hong Wei,\&Liang Junjun. (2017). College English teachers' self-concept, teaching efficacy and job burnout status and relationship research: Foreign Language Teaching Theory and Practice, 1, 53-59.

[3] Ibrahim, A.S., Al-Kaabi, A., \& El-Zaatari, W.J. (2013). Teachers resistance to educational change in the United Arab Emirates: International Journal of Research Studies in Education, 2, 77-95.

[4] Maslach, C. \& S. Jackson. (1981). "The measurement of experienced burn out": Journal of Occupational Behavior 2, 99-113.

[5] Maslach, C., S. Jackson \& M. Leiter. (1996). Maslach Burnout Inventory Manual. PaloAlto, CA: Consulting Psychology Press.

[6] Mckenzie, K., \& Scheurich, J. (2008). Teachers resistance to improvement of schools with diverse students: International Journal of Leadership in Education, 3, 89-105.

[7] Niu Lihua, \& Zou Meng. (2010). Teacher resistance in educational reform: Causes and responses to education: Foreign Education Research, 10, 18-21.

[8] Qiu Biqun. (2008). Investigation and analysis of job burnout of secondary school teachers in western Guangdong: Journal of southern China, 10, 82-83.

[9] Wang Fang, \& Xu Yan. (2004). Job burnout of primary and secondary school teachers and their relationship with social support: Journal of psychology, 36 (5), 568-574. 
[10] Xiao Hui. (2011). On the influence of rural teachers' Job Burnout on curriculum implementation: Contemporary Education Theory and Practice, 03 (1), 9-11.

Li Luo was born in Neijiang, China in 1989. She has received her Bachelor Degree in English education from China West Normal University, SiChuan NanChong, China in 2014. Importantly, she will receive her Graduate degree in Curriculum and teaching theory from China West Normal University, SiChuan NanChong, China in 2019.

She is currently an English teacher in the Nanchong Staff University in China. Her research interests include English education, Teaching method and literature.

She is good at helping the students to get high scores and pass English exam due to her special teaching skills and methods written and concluded by herself. 